\title{
Performance of Some Apple (Malus $\times$ domestica Borkh.) Cultivars for Fruit Quality Traits under Mid Hill Conditions of Himachal Pradesh, India
}

\author{
Praveen Verma ${ }^{*}$, B.S. Thakur and Nirmla Chauhan \\ Department of Fruit Science, Dr Y S Parmar University of Horticulture and Forestry, Nauni, \\ Solan-173230, Himachal Pradesh, India \\ *Corresponding author
}

A B S T R A C T

The present investigations entitled "Performance of some apple (Malus $\times$ domestica Borkh.) cultivars for fruit quality traits under mid hill conditions of Himachal Pradesh"

Keywords

Apple, Quality traits, Cultivars, Fruit characteristics, Early maturity

Article Info

Accepted:

06 December 2017

Available Online:

10 January 2018 were carried out in the experimental orchard of the HRTS and KVK, Kandaghat, Dr Yashwant Singh Parmar University of Horticulture and Forestry, Nauni, Solan (H.P.) during the year 2016 for their suitability for commercial cultivation. The experiment was laid out in Randomized Block Design with four replications. The observations were recorded on various parameters of fruit characteristics. Analysis of variance showed significant differences among all the cultivars for all the characters under study. Among different cultivars Early Red One, Scarlet Spur II, Oregon Spur II and Gale Gala were early in maturity. Highest yield was recorded in Gale Gala $(9.91 \mathrm{~kg} / \mathrm{tree})$. Maximum fruit length $(62.73 \mathrm{~mm})$ and diameter $(69.45 \mathrm{~mm})$ was recorded in Scarlet Spur II whereas, highest fruit weight $(155.75 \mathrm{~g})$ in cultivar Granny Smith. Highest TSS $\left(12.05^{\circ} \mathrm{B}\right)$ and total sugars $(9.59 \%)$ was recorded in cultivar Gale Gala while, highest ascorbic acid (7.95 $\mathrm{mg} / \mathrm{g}$ ) and total phenol content $(79.27 \mathrm{mg} / 100 \mathrm{~g})$ in cultivars Scarlet Spur II and Early Red One, respectively.

\section{Introduction}

Apple (Malus $\times$ domestica Borkh.) is one of the world's leading fruit crop widely grown, both in the Northern and Southern hemisphere. In India, apple cultivation is mostly confined to the states of Jammu \& Kashmir, Himachal Pradesh and Uttrakhand which together accounts for 99 per cent of the total production and the remaining is contributed by the states of Arunachal Pradesh, Nagaland, Tamilnadu and Sikkim. In Himachal Pradesh, total area under apple cultivation is 109553 ha which accounts for the production of 625199 MT fruits (Anonymous, 2015). Commercial apple industry in Himachal Pradesh is nearly 60 years old and comprises predominantly of the delicious group which constitutes 90 per cent of the varieties grown. These varieties significantly contributed towards apple production from mid-sixties to early 90's. However, under the changing climate scenario, these varieties started declining due to various biotic and abiotic stresses. Many production and protection problems took 
serious dimension in apple production leading to low productivity. Under the changing climatic conditions, these varieties did not perform satisfactorily in lower pockets or valley areas of the state especially with respect to colour development. These cultivars are now being replaced in a phased manner with low chill cultivars and high colour strains. On the other hand, there has been a shift in the area of apple production to higher elevations which is corroborated by a declining trend in snowfall over the years. In the recent past (1995-2000), large number of colour strains and varieties of apple were introduced in the state some of which have performed well under different agro climatic conditions. The best performing varieties were introduced at Horticulture Research and Training Station and Krishi Vigyan Kendra, Kandaghat in Solan district of Himachal Pradesh during 2005. In view of its regular fruiting under the prevailing mid hill conditions of the state and the potential it offers for fruit diversification as well as in view of its early maturity it was proposed to initiate the present study with the objective to study their fruit quality traits.

\section{Materials and Methods}

The present investigations were carried out in the experimental orchard of HRTS and KVK, Kandaghat, Dr Yashwant Singh Parmar University of Horticulture and Forestry, Nauni, Solan (H.P.) during the year 2016. The cultivars undertaken for studies included Early Red One, Scarlet Spur II, Oregon Spur II, Golden Delicious, Granny Smith, Gale Gala and Gibson Golden. Four trees of each cultivar were selected randomly.

\section{Physical fruit characteristics}

To study fruit characters, 20 representative fruit samples (5 in each replication) were taken at optimum maturity. The average length, diameter, weight and fruit volume was measured following standard procedure. The surface colour (ground colour and over colour) of the fruits were observed by comparing with the colour charts of the Royal Horticultural Society, London (Wilson, 1941). Fruit firmness was measured in $\mathrm{kg} / \mathrm{cm}^{2}$ and average of five fruits (each of 3 replicates) was worked out. Fruit shape, fruit texture and type of over colour were classified as per apple descriptor (Watkins and Smith, 1982).

\section{Biochemical fruit character}

The total soluble solid content of fruits was determined with by Erma hand refractometer (0-32 ${ }^{\circ}$ Brix $)$. Acidity, sugars and ascorbic acid content were estimated as per the standard procedures (A.O.A.C. 1980). TSS/acid ratio was worked out by dividing per cent TSS with per cent titratable acidity. Total phenols were determined by Folin and Ciocalteu procedure given by Singleton and Rossi (1965).

\section{Results and Discussion}

\section{Physical fruit characteristics}

Maximum fruit length $(62.73 \mathrm{~mm})$, diameter $(69.45 \mathrm{~mm})$ and fruit volume $\left(166.88 \mathrm{~cm}^{3}\right)$ was recorded in cultivar Scarlet Spur II whereas, minimum fruit length $(56.05 \mathrm{~mm})$, diameter $(65.29 \mathrm{~mm})$ and fruit volume $\left(127.50 \mathrm{~cm}^{3}\right)$ was recorded in Oregon Spur II and Gibson Golden, respectively.

Maximum fruit weight (155.75 g) was recorded in cultivar Granny Smith whereas, Oregon Spur II recorded the lowest fruit weight (116.71 g) (Table 3). The variation in size of the fruits have been reported by several workers (Rathore, 1986; Kumar and Verma, 2001; Sumrah et al., 2000; Sharma and Chauhan, 2008 and Singh, 2013) and is attributed to several factors like variety, soil, age and vigour of plant and orchard management practices being followed. 
Table.1 Fruit characteristics (physical) of some apple cultivars-II

\begin{tabular}{|c|c|c|c|c|c|c|}
\hline \multirow[t]{2}{*}{ Name of cultivar } & \multirow[t]{2}{*}{ Fruit shape } & \multirow{2}{*}{$\begin{array}{c}\text { Pedicel } \\
\text { length }(\mathrm{cm})\end{array}$} & \multicolumn{2}{|c|}{ Surface colour } & \multirow{2}{*}{$\begin{array}{l}\text { Type of over } \\
\text { colour }\end{array}$} & \multirow[t]{2}{*}{ Fruit texture } \\
\hline & & & Ground colour & Over colour & & \\
\hline Early Red One & Globose conical & 1.93 & Yellow Green 145 AB & Greyed Red 178 AB & Streaked & Intermediate \\
\hline Scarlet Spur II & Globose conical & 1.72 & Yellow Green 144 BC & Greyed Purple 145 AB & Splashed & Intermediate \\
\hline Oregon Spur II & Globose conical & 1.09 & Yellow Green 145 BC & Greyed Red 181 AB & Slightly blushed & Coarse \\
\hline Golden Delicious & Flat globose & 1.79 & Yellow Green 144 BC & No over colour & --------------- & Intermediate \\
\hline Granny Smith & Globose & 1.91 & Yellow Green 144 BC & No over colour & --------------- & Coarse \\
\hline Gale Gala & Flat globose & 2.34 & Yellow Green 145 BC & Greyed Red 179 AB & Splashed & Intermediate \\
\hline Gibson Golden & Globose & 2.20 & Yellow Green 144 AB & No over colour & --------------- & Intermediate \\
\hline C.D. $(0.05)$ & & 0.27 & & & & \\
\hline
\end{tabular}

Table.2 Fruit characteristics (chemical) of some apple cultivars

\begin{tabular}{|c|c|c|c|c|c|c|c|c|}
\hline Name of cultivar & $\begin{array}{l}\text { TSS } \\
\left({ }^{\circ} \mathbf{B}\right)\end{array}$ & $\begin{array}{c}\text { Titratable } \\
\text { acidity }(\%)\end{array}$ & $\begin{array}{l}\text { TSS/acid } \\
\text { ratio }\end{array}$ & $\begin{array}{c}\text { Total } \\
\text { sugars } \\
(\%)\end{array}$ & $\begin{array}{c}\text { Reducing } \\
\text { sugars } \\
(\%)\end{array}$ & $\begin{array}{l}\text { Non-reducing } \\
\text { sugars }(\%)\end{array}$ & $\begin{array}{c}\text { Ascorbic } \\
\text { acid } \\
\text { (mg/100g) }\end{array}$ & $\begin{array}{c}\text { Phenol } \\
\text { content } \\
\text { (mg/100g) }\end{array}$ \\
\hline Early Red One & 10.08 & 0.69 & 14.97 & 9.18 & 6.15 & 2.87 & 7.68 & 79.27 \\
\hline Scarlet Spur II & 10.60 & 0.82 & 13.11 & 9.05 & 5.68 & 3.20 & 7.95 & 44.89 \\
\hline Oregon Spur II & 9.93 & 0.92 & 10.86 & 9.22 & 6.13 & 2.93 & 6.90 & 55.47 \\
\hline Golden Delicious & 9.98 & 0.64 & 15.87 & 9.58 & 6.04 & 3.36 & 7.02 & 55.29 \\
\hline Granny Smith & 9.60 & 0.70 & 13.76 & 8.73 & 5.84 & 2.74 & 7.23 & 50.18 \\
\hline Gale Gala & 12.05 & 0.86 & 14.01 & 9.59 & 5.99 & 3.42 & 5.75 & 51.41 \\
\hline Gibson Golden & 9.83 & 0.68 & 14.91 & 9.16 & 5.25 & 3.71 & 6.48 & 54.06 \\
\hline C.D. $(0.05)$ & 0.36 & 0.12 & 2.56 & 0.48 & 0.39 & 0.60 & 0.98 & 4.96 \\
\hline
\end{tabular}


Table.3 Fruit characteristics (physical) of some apple cultivars-I

\begin{tabular}{|l|c|c|c|c|c|c|}
\hline Name of cultivar & $\begin{array}{c}\text { Fruit length } \\
(\mathbf{m m})\end{array}$ & $\begin{array}{c}\text { Fruit diameter } \\
(\mathbf{m m})\end{array}$ & $\begin{array}{c}\text { L/D } \\
\text { ratio }\end{array}$ & $\begin{array}{c}\text { Fruit } \\
\text { weight } \\
(\mathbf{g})\end{array}$ & $\begin{array}{c}\text { Fruit volume } \\
\left(\mathbf{c m}^{\mathbf{3}}\right)\end{array}$ & $\begin{array}{c}\text { Fruit } \\
\text { firmness } \\
\left(\mathbf{k g} / \mathrm{cm}^{2}\right)\end{array}$ \\
\hline Early Red One & 62.51 & 68.00 & 0.92 & 143.46 & 163.94 & 14.05 \\
\hline Scarlet Spur II & 62.73 & 69.45 & 0.90 & 149.64 & 166.88 & 14.05 \\
\hline Oregon Spur II & 56.05 & 65.84 & 0.85 & 116.71 & 140.31 & 14.05 \\
\hline Golden Delicious & 60.51 & 65.65 & 0.92 & 124.26 & 128.13 & 13.18 \\
\hline Granny Smith & 62.64 & 67.14 & 0.93 & 155.75 & 157.50 & 14.10 \\
\hline Gale Gala & 57.39 & 66.24 & 0.87 & 117.35 & 153.75 & 13.98 \\
\hline Gibson Golden & 60.33 & 65.29 & 0.92 & 125.18 & 127.50 & 15.05 \\
\hline C.D. (0.05) & 4.83 & 1.84 & 0.05 & 17.65 & 9.65 & 0.39 \\
\hline
\end{tabular}

The fruits shapes under the present investigations have been recorded as per the apple descriptor developed by Watkins and Smith, (1982). Maximum pedicel length was recorded in Gale Gala $(2.34 \mathrm{~cm})$ while, it was minimum in Oregon Spur II $(1.09 \mathrm{~cm})$. The observations were recorded on the development of ground and over colour in different cultivars under study. Early Red One, Oregon Spur II and Gale Gala were recorded to have Greyed Red over colour which belongs to the Group $178 \mathrm{AB}$, Group $181 \mathrm{AB}$ and Group 179 AB respectively. The cultivar Scarlet Spur II was recorded to have Greyed Purple over colour which belongs to the Group 145 AB.

The ground colour of all the cultivars under study were recorded to have Yellow Green which belongs to the Group $144 \mathrm{AB}$ for cultivars Gibson Golden, Group 144 BC for Scarlet Spur II, Golden Delicious and Granny Smith, Group 145 BC for Oregon Spur II and Gale Gala and 145 AB for Early Red One. The type of over colour in different apple cultivars varied significantly. The fruit blush was streaked in cultivar Early Red One, splashed in cultivars Scarlet Spur II and Gale Gala and was recorded as slightly blushed in cultivar Oregon Spur II (Table 1). The blush was absent in cultivars Golden Delicious, Granny Smith and Gibson Golden. Fruit texture was coarse in cultivar Oregon Spur II and Granny Smith whereas, it was intermediate in all other cultivars under study.

\section{Biochemical fruit character}

The data presented in Table 2 revealed that the highest TSS $\left(12.05^{\circ} \mathrm{B}\right)$ was recorded in cultivar Gale Gala whereas; minimum TSS $\left(9.60^{\circ} \mathrm{B}\right)$ was recorded in Granny Smith. The highest titratable acidity $(0.92 \%)$ was recorded in cultivar Oregon Spur II followed by Gale Gala $(0.86 \%)$ and minimum $(0.64 \%)$ was recorded in Golden Delicious. The highest TSS/acid ratio (15.87) was recorded in the cultivar Golden Delicious and minimum acidity (10.86) was recorded in Oregon Spur II. A maximum total sugar was recorded in Gale Gala $(9.59 \%)$ and it was minimum in Granny Smith $(8.73 \%)$. The maximum reducing sugars $(6.15 \%)$ was recorded in cultivar Early Red One while, Gibson Golden recorded the lowest reducing sugar $(5.25 \%)$. Whereas, nonreducing sugars was maximum in Gibson Golden (3.71 \%) and lowest in Granny Smith (2.74\%). Ascorbic acid content was maximum in Scarlet Spur II (7.95 mg/100g) and was minimum in Gale Gala $(5.75 \mathrm{mg} / 100 \mathrm{~g})$. Maximum total phenol content was recorded in Early Red One $(79.27 \mathrm{mg} / 100 \mathrm{~g})$ and it was minimum in Scarlet Spur II (44.89 mg/100g). (Table 2). 
Lot of work has been done on the physicochemical characteristics of different apple varieties throughout the world. These parameters may vary from place to place depending on climatic factors and management practices. In the foregoing discussion on physico-chemical characteristics (TSS, acidity, total sugars, reducing sugars, non-reducing sugars, phenols etc.) of different cultivars, the results are within the limited range but shows slight variation compared with the findings of other workers. Similar variation for chemical characteristics like TSS, acidity, sugars etc. have also been reported from different parts of the state of Himachal Pradesh, Uttrakhand and Jammu \& Kashmir. Kumar and Verma (2001) under mid hill conditions of Kullu; Dwivedi et al., (2005) in Ladakh region of Jammu \& Kashmir; Sharma and Chauhan (2008) in dry temperate conditions of Spiti; Sharma (2011) under mid hill conditions of Sirmour and Singh (2013) under dry temperate region of Kinnaur.

From the present work it is concluded that the cultivars Early Red One, Scarlet Spur II, Oregon Spur II and Gale Gala can be recommended for commercial cultivation under mid hill conditions of Himachal Pradesh because of their early maturity $\left(2^{\text {nd }}\right.$ week of July) and development of a uniform over colour over the entire fruit.

\section{Acknowledgements}

A special thanks to Dr YS Parmar University of Horticulture and Forestry, Nauni, Solan, (HP) for providing support and necessary facilities for this research work.

\section{References}

A.O.A.C. 1980. Association of Official Analytical Chemists. Official Methods of Analysis. Hortwitz, W. (ed.), $13^{\text {th }}$ edn. Washington, D.C. 1015 p.

Anonymous. 2015. Horticulture development in Himachal Pradesh at a glance. www.hpagrisnet.gov.in

Dwivedi SK, Abdul K and Raut B. 2005. Some fruit characteristics of apple varieties indigenous to Ladakh, India. Acta Horticulturae, 696:53-55.

Kumar J and Verma HS. 2001. Performance of apple cultivars under low altitude conditions of Kullu Valley. Haryana Journal of Horticultural Sciences, 30:139-142.

Rathore DS. 1986. Preliminary evaluation of genetic resources of apple. In: Advances in Research on Temperate Fruits. (Chadha TR, Bhutani VP and Kaul JL eds). Proceedings of national symposium on 'Temperate Fruits', held from March 15-18, 1984 at Dr YS Parmar University of Horticulture and Forestry, Solan. pp. 3-6.

Sharma DP and Chauhan JS. 2008. Performance of apple cultivars under cold dessert conditions of NorthWestern Himalayas. Acta Horticulturae, 772:199-201.

Sharma HR. 2011. Performance of Some Apple Cultivars under Sub Temperate Conditions of Himachal Pradesh (Malus $\times$ domestica Borkh.). M.Sc. Thesis. Department of Fruit Science, Dr YS Parmar University of Horticulture and Forestry, Solan. $53 \mathrm{Pp}$.

Singh J. 2013. Studies on the performance of some newly introduced cultivars of apple (Malus $\times$ domestica Borkh.) under high hill conditions of Kinnaur (H.P.). M.Sc. Thesis. Department of Fruit Science, Dr YS Parmar University of Horticulture and Forestry, Solan. 56 $\mathrm{Pp}$.

Singleton, V.L. and Rossi, J.A. 1965. Colorimetry of total phenolics with phosphomolybedic phosphotungstic 
acid reagents. American J. Enology and Viticulture, 16:144-158.

Sumrah MA, Nasir MM, Allah B and Nawaz MZ. 2000. The performance of some apple cultivars under sub mountain climatic conditions. Sarhad Journal of Agriculture, 16:393-395.

Watkins R and Smith RA. 1982. Apple descriptors. International Board for Plant Genrtic Resources. IBPGR SECRETARIAT Rome. 49p.

Wilson RW. 1941. Horticultural Colour Charts I and II. Wilson Colour Ltd. In collaboration with the Royal Horticultural Society, England.

\section{How to cite this article:}

Praveen Verma, B.S. Thakur and Nirmla Chauhan. 2018. Performance of Some Apple (Malus $\times$ domestica Borkh.) Cultivars for Fruit Quality Traits under Mid Hill Conditions of Himachal Pradesh, India. Int.J.Curr.Microbiol.App.Sci. 7(01): 788-793. doi: https://doi.org/10.20546/ijcmas.2018.701.096 